\begin{tabular}{ccc}
\hline International Journal of Engineering \& Technology, $7(4.13)(2018) 112-119$ \\
SPC & Website: www.sciencepubco.com/index.php/IJET \\
Research paper & International Journal of Engineering \& Technology \\
\hline
\end{tabular}

\title{
A case study of LEAN application for shortest lead time in composite repair shop
}

\author{
Fadzil Adly Ishak ${ }^{1}$, Muhd Khudri Johari ${ }^{1}$, Rozzeta Dolah ${ }^{2,3}$ \\ ${ }^{1}$ Universiti Kuala Lumpur - Malaysian Institute of Aviation Technology, Dengkil, Selangor, Malaysia \\ ${ }^{2}$ Universiti Teknologi Malaysia, Kuala Lumpur, Malaysia \\ ${ }^{3}$ Massachusetts Institute of Technology, Massachusetts, USA \\ *Corresponding author E-mail: fadziladly@unikl.edu.my
}

\begin{abstract}
Lean tools and applications have been adopted globally by many companies and industries such as automotive, aerospace, healthcare, pharmaceutical, shipbuilding, public services, project management and several others. The most basic of lean tools can be distinguished by the following: Value Stream Mapping (VSM), 5S and Kaizen, and many have agreed that these are the best selections in the initial approach of lean system and these techniques are part of the Y Management System (YMS) initiatives. This research is intended to make VSM as the primary working culture, which has been proven suitable to the servicing companies that conduct Maintenance, Repair and Overhaul (MRO) activities. With full cooperation from Company X Sdn. Bhd., researchers were able to review and later harmonize the implementation flow of VSM with the intentions to increase their personnel's production rate significantly. The rudder repair project involving the maintenance of Royal Military Airforce's Skyhawk aircraft has been given the opportunity to be experimented with VSM. After the analysis of all 53 personnel involved, it can be concluded that the lean implementation has considerably improved their individual performances, organizational behaviours, future work mapping and personal/team workstations.
\end{abstract}

Keywords: lean implementation; VSM; rudder repair program.

\section{Introduction}

Company X Sdn. Bhd. has been incorporated in November 1990 with the objective to develop and expand the aerospace and composite industry in Malaysia. The company is engaged in the manufacturing of commercial and also military aerospace composites. It offers unmanned system technology, aerospace design, composites engineering, system integration, composite design and assembly, composite repair, engineering and design, system software development, aircraft leasing, aircraft schedule and unscheduled maintenance, aircraft avionics upgrade and modification, aircraft structural modification handling and hangar services, aircraft maintenance, aircraft repair and overhaul, wing panels, fan cowls, material testing capability, composites for automotive, homeland security and maritime industries. As of November 4, 2013, Composites Technology Research Malaysia Sdn. Bhd. has started to operate as a subsidiary of Z-Y Sdn. Bhd. Company X has obtained numerous approvals such as A1 Primary Company for the design, manufacture and assemble of the Eagle 150 Series aircraft, Part 145 Maintenance Approval of various types of aircraft and component from various national authorities such as the Department of Civil Aviation Malaysia (DCAM), Directorate General of Civil Aviation, Indonesia, Department of Civil Aviation Thailand and the latest approval from the Federal Aviation Administration (FAA) of the USA for composite repair shop capabilities. In obtaining the approval, supports from the top management and continuous effort and cooperation from the operational personnel are crucial. As one of its operators, Company $\mathrm{X}$ is proud to adopt the Z-Y's Y Management System (YMS), which can be referred to as lean manufacturing, enterprise or business. This means that the company is focused on the requirement and needs from the customer that the product of service must be free of defects, obtain the product in the exact time as schedule and have minimal wastes during the process. The objectives behind the system are to do things better and faster, avoid unnecessary tasks and reduce waste of any kind in principle. Company $\mathrm{X}$ has been selected as the organization for a case study for the project, and this will further help the company to identify gaps on lean or YMS program amongst their employees and determine whether the program will make the operational and working environment better and benefit either for the short and long terms business operations.

For this purpose, Value Stream Mapping (VSM) has been chosen since it is one of the key lean tools used to identify the opportunities for various lean techniques. Variation of pre- and post- lean initiatives reduces the production's lead-time and redundant tasks in the process inventory. Both value-added and non-value-added approaches have been analyzed through VSM as a visual tool to help reveal the hidden waste and sources of waste [1]. This project focuses mainly on the waste elimination through the implementation of VSM in the composite repair workshop and relevant work centres (other departments that are affected by the process flow in the composite repair program) such as the Project Office, Planning Department, Quality Department, Engineering and Technical Services (ETS) Department and bonded warehouse. This value stream perspective does not reflect the general working processes of the process industries. The scope of study is focused only on the VSM which produces the map of operating state of the composite repair process. This map is used to identify sources of waste and identify other possible lean tools that may be suitable for reducing wastes in workshop processes. 


\section{Value Stream Mapping (VSM)}

VSM has already been defined extensively by philosophers and also academicians in the recent years. For some, it is a visual way of representing the flow of information and material in production environment $[2,3]$. This creates a simple way for the organisation to see the value flow. It is originally developed as the method for analysis and optimization of the industrial processes. VSM is an effective method of gaining the holistic overview of value stream within an organization $[4,5]$. VSM helps management to visualise information and product flow, waste and also relationship between information and material flow [6]. Based on current state analysis, flow-oriented target value streams are planned and implemented $[7,8]$. A value stream includes all activities such as value-adding, non value-adding and supporting processes that are necessary to create a product and to make it available for the customers [9].

The study is focused on repairs performed on a RMAF Skyhawk's rudder with the part number KB554L0165-000. The repair is categorized under metal bonding repair where the steps of repair are slightly different to the other composite repair schemes. However, some of the processes are common and the workshop, facilities, tools and equipment used are still utilized in the same manner with appropriate required skills of the technical personnel. The on-wing inspections have been conducted at the RMAF facilities in Kuantan, Pahang. Typical damage in honeycomb has been found to be the corrosion around the inspection holes of Hawk Mark 108/208 aircraft rudder. Most of the rectifications have been to remove the skin with the greatest area of disbonding. The damage core section must be removed and replaced with new core section A new skin shall be bonded onto the replaced core. The replacement items are largely in one-for-one replacement with the original structure. The composite repair process is similar in procedures and steps taken as with other composite OEM but it must be of different or special process treatment and finishing for the repair, which is referred to the design basis of the component structure. The repair procedure has been developed to enable easy removal of the damaged structure and replacing it with new serviceable items. The replacement items are often one-for-one replacement with the original structure.

The rudder has been fabricated as a sandwich-type structure fabricated with 2024-T3 Al Clad and 5052 core materials through the bonding process. The repair process consists of few steps: damage assessment, disassembly, skin and core removal, preparation of repair, inspect edge members, preparation of core, preparation of rudder bonding, install core, curing process bagging and oven, inspection 1 and preparation, preparation of skin and splice, install skin and splice, final cure, inspection 2, reassembly 1 , painting, reassembly 2 , identification of mod plate, control surface balancing, final inspection, engineering verification, certification of conformance and issuance, and TUDM rigging verification on aircraft.

\section{Methodology}

A preliminary visit and facility tour at Company $\mathrm{X}$ is carried out through careful observation of their current operation, workplace environment and working conditions. The visit is started from the management office before continuing to their production shop and wrapped up at their composite repair workshop. This exercise is conducted to have a clearer picture of MRO activities, operation types and projects undertaken, specifically of interest in this study is the rudder repair program. Further discussions with the program team has been conducted to identify the essential problems faced by the team. The problems would be cross-referenced with wastes in the lean philosophy.

\subsection{Types of wastes in lean}

Table 1 shows the exact types of wastes that have been announced and published by United States' Environmental Protection Agency recently [10].

\begin{tabular}{|c|c|c|}
\hline Waste Type & $\begin{array}{l}\text { Targeted by Lean } \\
\text { Methods }\end{array}$ & Service Sector Wastes \\
\hline Defects & $\begin{array}{c}\text { Scrap, rework, } \\
\text { replacement } \\
\text { production, inspection }\end{array}$ & $\begin{array}{l}\text { Order entry, design or } \\
\text { engineering errors }\end{array}$ \\
\hline Waiting & $\begin{array}{l}\text { Stock-outs, lot } \\
\text { processing delays, } \\
\text { equipment downtime, } \\
\text { capacity bottlenecks }\end{array}$ & $\begin{array}{l}\text { System downtime, } \\
\text { response time, } \\
\text { approvals }\end{array}$ \\
\hline Overproduction & $\begin{array}{l}\text { Manufacturing items for } \\
\text { which there is no order }\end{array}$ & $\begin{array}{l}\text { Printing paperwork, } \\
\text { purchasing items } \\
\text { before they are needed, } \\
\text { processing paperwork } \\
\text { before the next person is } \\
\text { ready for it }\end{array}$ \\
\hline Transportation & $\begin{array}{l}\text { Transporting work-in- } \\
\text { progress (WIP) long } \\
\text { distances, trucking to and } \\
\text { from an off-site storage } \\
\text { facility }\end{array}$ & $\begin{array}{l}\text { Multiple sites outside of } \\
\text { walking distance, off- } \\
\text { site training }\end{array}$ \\
\hline Inventory & $\begin{array}{l}\text { Excess raw material, } \\
\text { WIP or finished goods }\end{array}$ & $\begin{array}{l}\text { Office supplies, sales } \\
\text { literature and reports }\end{array}$ \\
\hline Complexity & $\begin{array}{c}\text { More parts, process steps } \\
\text { or time than } \\
\text { necessary to meet } \\
\text { customer needs }\end{array}$ & $\begin{array}{l}\text { Re-entry of data, extra } \\
\text { copies, excessive } \\
\text { reporting, etc. }\end{array}$ \\
\hline $\begin{array}{l}\text { Unused } \\
\text { creativity }\end{array}$ & $\begin{array}{l}\text { Lost time, ideas, skills, } \\
\text { improvements, and sug- } \\
\text { gestions from } \\
\text { employees }\end{array}$ & $\begin{array}{c}\text { Limited tools or } \\
\text { authority available to } \\
\text { employees to carry-out } \\
\text { basic tasks }\end{array}$ \\
\hline
\end{tabular}

In order to effectively maximize profits and minimize costs, lean tools are adopted for various operations in a company, which limit utilization of work essentials such as equipment, space, time and energy in producing the work outputs. This has been reaffirmed through efforts in fulfilling distinctive customers' various requests and demands, which usually generate wastes in the process. This regular occurrence contradicts the basic concept of doing business: maximizing profits and minimizing losses. For that, the previous studies have listed seven major wastes in lean: defects, inventory, over-processing, waiting time, transportation, over-production and motion are identified as seven major wastes in lean $[11,12]$.

\subsection{VSM implementation}

During the implementation of VSM, initial analysis was taken to have an overview of the rudder repair process that could identify the potential process for improvement. The supplier and Engineering Design Support Network by Company $\mathrm{Z}$ were identified to be the inbound supply chain for the repair program. The flow of the communication, correspondences and information for analysis of damages required demanding time allocations to ensure the repairs that had been carried out is to be at least as good as the original state. The information flow between the Engineering and Technical Support (ETS) Department of Company X and Company Z had intensive iteration to attain the level of quality to establish the details of repair work procedures. Table 2 describes the sequence of the rudder repair program and highlights the internal production process for rudder repair in a typical composite repair shop.

Meanwhile, the Program Office has started to communicate simultaneously with the supplier and engineering and technical support department for materials use and purchases to support the repair program without causing any further delay to production. Once the repair work analysis had been completed by Company Z, the repair scheme had to be established and forwarded to ETS Department to be organized into systematic arrangement of internal engineering organization documents that was then distributed to the planning department for task planning and scheduling of all relat- 
ed department such as quality, warehouse and production workshop. Program office played the core roles in the repair program, managing and monitoring a smooth program flow and high efficiency. However, this value stream perspective does not reflect general working

Table 2: Production process for rudder repair in composite repair shop

\begin{tabular}{|c|c|c|}
\hline No. & Process Title & Process Description \\
\hline 1 & $\begin{array}{l}\text { Damage } \\
\text { assessment }\end{array}$ & $\begin{array}{l}\text { Visual inspection to be carried out to check the } \\
\text { evidence of corrosion or other damages and } \\
\text { extend of damages. Mark area of } \\
\text { disbonding and damages. }\end{array}$ \\
\hline 2 & Disassembly & $\begin{array}{l}\text { Removal of leading edge balance weight, upper } \\
\text { and lower link, leading edge D-nose, trailing } \\
\text { edge strakes and paint strip. }\end{array}$ \\
\hline 3 & $\begin{array}{l}\text { Skin and core } \\
\text { removal }\end{array}$ & $\begin{array}{l}\text { Removal of skin and core of rudder. Skin with } \\
\text { the most corrosion or damages to me remove } \\
\text { first. Dry ice is used to ease the removal. }\end{array}$ \\
\hline 4 & $\begin{array}{l}\text { Preparation of } \\
\text { repair }\end{array}$ & $\begin{array}{l}\text { Fabrication of repair disc for inspection holes, } \\
\text { repair skin and repair splice to match forward } \\
\text { edge of removal skin and the lips at the } \\
\text { interface with the D-nose. Water break test is } \\
\text { performed on fabricated part and primer coat- } \\
\text { ing. }\end{array}$ \\
\hline 5 & $\begin{array}{l}\text { Inspect edge } \\
\text { members }\end{array}$ & $\begin{array}{l}\text { Visual Inspection to be carried out on the } \\
\text { inner surface of edge members to ensure no } \\
\text { evidence of damage. }\end{array}$ \\
\hline 6 & $\begin{array}{l}\text { Preparation of } \\
\text { core }\end{array}$ & $\begin{array}{l}\text { Replacement of core material with the approved } \\
\text { types as stated in Engineering Order. Core cut- } \\
\text { ting to be in accordance to profile. }\end{array}$ \\
\hline 7 & $\begin{array}{l}\text { Preparation of } \\
\text { rudder bond- } \\
\text { ing }\end{array}$ & $\begin{array}{l}\text { Water break test is performed on bared metal on } \\
\text { bonding surface and primer coating. }\end{array}$ \\
\hline 8 & Install core & $\begin{array}{l}\text { Release film preparation on all bonding } \\
\text { surface, and core installation. }\end{array}$ \\
\hline 9 & $\begin{array}{l}\text { Curing } \\
\text { process } \\
\text { bagging and } \\
\text { oven }\end{array}$ & $\begin{array}{l}\text { Placement of rudder assembly on repair jig, } \\
\text { preparation of thermocouples on part, vacuum } \\
\text { bagging and oven curing. }\end{array}$ \\
\hline 10 & $\begin{array}{l}\text { Inspection and } \\
\text { preparation }\end{array}$ & $\begin{array}{l}\text { Visual Inspection to be carried out on the } \\
\text { adhesive flow on the core at bondline. Flatness } \\
\text { of core to be checked and core flushed. }\end{array}$ \\
\hline 11 & $\begin{array}{l}\text { Preparation of } \\
\text { skin and slice }\end{array}$ & $\begin{array}{l}\text { Water break test is performed on } 2^{\text {nd }} \text { skin and } \\
\text { application of adhesive film on the bonding area. }\end{array}$ \\
\hline 12 & $\begin{array}{l}\text { Install skin } \\
\text { and splice }\end{array}$ & $\begin{array}{l}\text { Application of adhesive film between core and } \\
\text { trailing edge spacer. Vacuum bagging prepara- } \\
\text { tion on assembly, and application of mechanical } \\
\text { weight. }\end{array}$ \\
\hline 13 & Final cure & $\begin{array}{l}\text { Preparation and application of oven curing as per } \\
\text { approved curing recipe under elevated high } \\
\text { temperature. }\end{array}$ \\
\hline 14 & Inspection 2 & $\begin{array}{l}\text { Inspection on repair assembly and the straight- } \\
\text { ness of trailing edge to be checked. }\end{array}$ \\
\hline 15 & Re-assembly 1 & $\begin{array}{l}\text { D-nose reassembled and trailing edge strakes } \\
\text { installation. }\end{array}$ \\
\hline 16 & Painting & $\begin{array}{l}\text { Protection form corrosion with primer coating } \\
\text { and finishing with approved paint coating. }\end{array}$ \\
\hline 17 & Re-assembly 2 & $\begin{array}{l}\text { Installation of upper and lower link assembly } \\
\text { and installation of rudder balance in } \\
\text { accordance with Aircraft Maintenance } \\
\text { Manual. }\end{array}$ \\
\hline 18 & $\begin{array}{l}\text { Identification } \\
\text { on mod plate }\end{array}$ & Rudder modification plate marked. \\
\hline 19 & $\begin{array}{l}\text { Control } \\
\text { surface } \\
\text { balancing }\end{array}$ & $\begin{array}{l}\text { Rudder balancing check performed for top, cen- } \\
\text { tre and bottom balance weight. Thickness of } \\
\text { packers recorded and finally weight of rudder to } \\
\text { be carried out. }\end{array}$ \\
\hline 20 & $\begin{array}{l}\text { Final } \\
\text { inspection }\end{array}$ & Final inspection performed by Quality. \\
\hline 21 & $\begin{array}{l}\text { Engineering } \\
\text { verification }\end{array}$ & $\begin{array}{l}\text { Verification of repair work performed as per } \\
\text { work instruction by the Senior Design Engineer. }\end{array}$ \\
\hline 22 & $\begin{array}{l}\text { Certificate of } \\
\text { conformance } \\
\text { and issuance }\end{array}$ & $\begin{array}{l}\text { Certificate of conformance }(\mathrm{C} \text { of } \mathrm{C}) \text { and } \\
\text { Certificate of Origin }(\mathrm{C} \text { of } \mathrm{O}) \text { issuance in } \\
\text { accordance with all applicable instructions, } \\
\text { specifications and contract requirements. }\end{array}$ \\
\hline 23 & Packaging & $\begin{array}{l}\text { Repaired rudder packed for delivery by ware- } \\
\text { house. }\end{array}$ \\
\hline 24 & TUDM & Final verification by TUDM personnel on the \\
\hline
\end{tabular}

\section{Rigging actual aircraft for final rigging process.}

verification on

aircraft

processes of the industries but rather the scope of study was only focused on the internal production process of the rudder repair. The involvement was of physical works of the processes, which were considered to have direct contacts to the affected part and most processes were related to individual process in the specific workshop.

An improvement team had been established to identify the value flow of production process, which consists of three personnel: one personnel from workshop, one personnel from the Program Office, and one personnel from the Quality Department. Gemba walk was performed by the team to discover issues to the flow that need to be fixed and rectified. This platform has provided the opportunities to the management and operators to do the right things in the first place and recognize any waste that needs improvement. The Gemba walk is a way of supporting the continuous improvement through assistance and supports from the leaders, who are responsible to respective workshops such as supervisors and managers who handle and manage their respective department to support any kind of projects and programs in organization [13]. This process helps building relationships amongst team leaders and team members by getting to know the real function and specific task undertaken, and further help them to improve the processes. The practices have improved the effectiveness of staff and discovered few opportunities for improvement through the responses to the questions highlighted by the team leaders. The simple explanation and presentation, however, in general had given them some basics philosophy about VSM. The Gemba walk was then finally focused down to specific processes which were the target for improvement, such processes that heavily time consuming and critical procedure which need precision techniques.

Current state map of processes was drawn after the completion of Gemba walk. All measurement data such as the staffs' movements and the distances throughout the production of rudder repair were recorded. The source of wastes was identified and this had opened opportunity for the next stage in the implementation of other lean techniques. Creating a value stream map is to group and illustrate information and process flow, timelines and other associated data such as communication, people and transportation. The analysis of value chain through general VSM provided details of operation for composite repair shop activities and also showed the potentials for improvement. It started with two components: general picture of mapping and detailed mapping. The overview of general picture illustrates the key features of the entire process that are essential for detailed process mapping. Basic steps for the establishment of the VSM are listed as follow:

- $\quad$ Step 1: supplier, input processes, output and customer within the value stream were identified

- Step 2: process data that includes cycle times and lead times were collected

- Step 3: Gemba walk throughout actual process of composite repair activities carried-out and the system through quantify value-added, non value-added component of each particular activities were analysed and weaknesses identified.

- $\quad$ Step 4: Current-state value stream map was drawn by using detailed tooling icons and techniques. The icons used are unique in visually representing various tasks and functions.

The current state was utilised to focus on improvement efforts. All non-value added times or wastes were identified and recognised as potential aspects for improvement. After the completion of current state map, subsequent measure was to draw future state map based on an improvement plan. This future map then becomes the basis for making the necessary changes to process and activities. Future state map was developed for the system as VSM clearly indicates the inventory, process time, lead time, waiting time, etc. and the process flow can be sorted out [14]. The case study investigated the "before" and "after" scenarios, through simulation that had 
helped to illustrate potential benefits such as reduced production lead time and minimal work in process inventory.

From this point moving forward, VSM was introduced and briefed to all 53 personnel involved before it was used to map out the current operating states for the rudder repair program. During the implementation, all applicable data were determined and recorded for evaluations. This concept was actually adopted from Liu $e t$ al. on lean transformation for composite material bonding processes of the small-medium production scale [15]. Figure 1 illustrates the researchers' own process flow of operational framework for this reseach study.

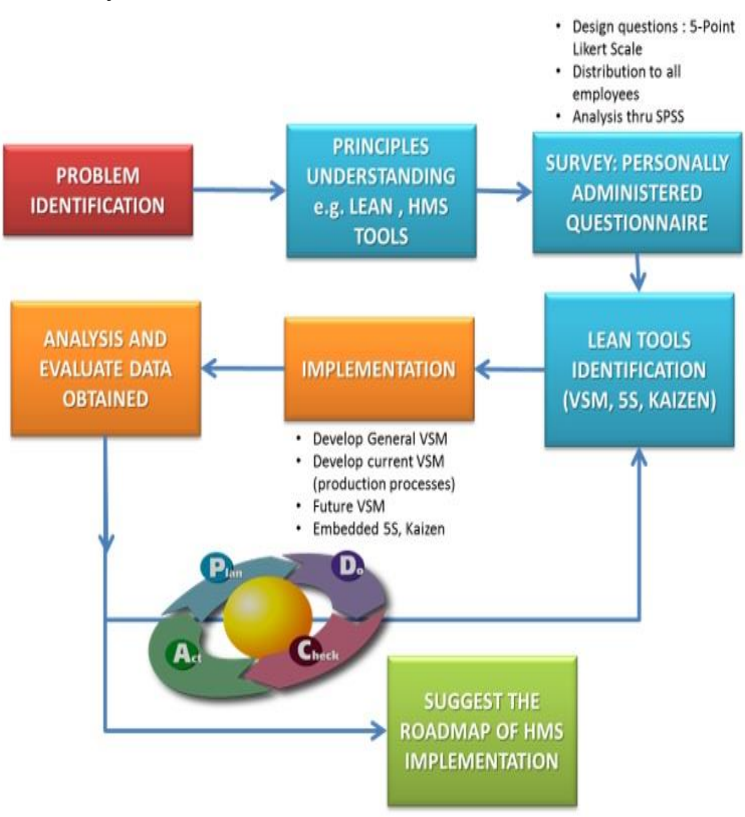

Fig. 1: Process flow of operational framework

\subsection{Demographic}

From 53 personnel involved, the management team was consisted of 11 employees, non-management team had 14 employees while the remaining balance of 28 employees were in the operation staff category. The collective data were then analysed and identified to measure the performance as outlined in the project details. Among the indicators used were number of processess in the rudder repair, total distances of part and staff movements, total production cycle time, total waiting time, total production lead-time, total setup time, total inspection time, total manpower in time-shift, time-shift per day, total value and non-value added activities, and production efficiencies.

\section{Results and discussions}

\subsection{Current state map and future state map}

The analysis of results were done through descriptive analysis that described the characteristics of focused dataset for given situation before they were recorded and analysed for improvement purposes. From the data collection, comparisons were performed to identify 13 measures of performance, before and after the implementation of the lean approach. Value added and non-value added were identified and analysed through a series of lean implementation. The required data was determined through the current state map in Figure 2 and the future state map in Figure 3.

Various sources of waste from each production process involved are highlighted in Figure 2. In terms of the cycle time and waiting time, productions' planning and scheduling processes must be improved as they require substantial process times. On the other hand, Figure 3 indicates that with the strategic merges of certain operations, significant improvement in terms of both planning and scheduling management had been successfully recorded. As for the selection of Kaizen, which can be seen as highlighted in burst marks, they imply areas for further improvement. Both introduced shift-working times in two processes to accommodate the timeconsuming processes such as damage removal and preparation of repair and inspection. Based on the records, total steps of rudder repair process had been reduced to 16 work processes with total cycle time of 6403 minutes and waiting time of 156.45 hours.

\subsection{Improvements}

The Gemba walk route through production flow was then recorded in terms of the time taken for part and staff movements, and the distance was calculated from the starting point of production repair up to the following processes. Among the workshop that was used for the repair were Clean Room Level 2, Oven shop, Warehouse 1, Trim shop, Paint shop and Quality Assurance. The time taken and the distance movement of rudder repair are shown in Table 3, which recorded that the total distances and movement of part or staff is 716.28 meters that takes up 813.00 seconds of time recorded. Table 4 indicated improvements of those data, showing 358.14 meters that takes up 388.00 seconds for time total distances and movement of part or staff, respectively. Since the facility of Company $\mathrm{X}$ was specifically designed for aircraft storage hangar, due to the demands and requirement of business operation, the site is now diversified to accommodate the other MRO operations and most of the hangars has been fully occupied with specific function and the equipment remain fixed. Nothing much can be done to minimize the wastes, unless a new set up of facilities design and arrangements is in place. The optimization of the space and layout of the individual workshop could help in reducing the mentioned waste.

Table 3: Time taken and distance of staff and part movement for rudder repair in current state map

\begin{tabular}{|c|c|c|c|}
\hline Process & Location & $\begin{array}{c}\text { Walking } \\
\text { Distances (m) }\end{array}$ & $\begin{array}{c}\text { Time Taken } \\
\text { (sec) }\end{array}$ \\
\hline $1 \rightarrow 2$ & $\begin{array}{c}\text { Warehouse to } \\
\text { Quality } \\
\text { Department }\end{array}$ & 38.1 & 47 \\
\hline $2 \rightarrow 3$ & $\begin{array}{c}\text { Quality } \\
\text { Department to } \\
\text { Composite Shop } \\
\text { Level } 2\end{array}$ & 76.2 & 78 \\
\hline $3 \rightarrow 4,5$ & $\begin{array}{c}\text { Composite Shop } \\
\text { Level } 2 \text { to Trim } \\
\text { Shop } \\
\end{array}$ & 38.1 & 73 \\
\hline $4,5 \rightarrow 6,7$ & $\begin{array}{c}\text { Trimming Shop to } \\
\text { Composite Shop } \\
\text { Level } 2\end{array}$ & 38.1 & 73 \\
\hline $6,7 \rightarrow 8$ & $\begin{array}{c}\text { Clean Room Level } \\
2 \text { to Oven }\end{array}$ & 22.86 & 20 \\
\hline $8 \rightarrow 9$ & $\begin{array}{c}\text { Oven to Quality } \\
\text { Department }\end{array}$ & 68.58 & 55 \\
\hline $9 \rightarrow 10,11$ & $\begin{array}{c}\text { Quality } \\
\text { Department to } \\
\text { Composite Shop } \\
\text { Level } 2\end{array}$ & 76.2 & 78 \\
\hline $\begin{array}{c}10,11 \rightarrow \\
12\end{array} \rightarrow$ & $\begin{array}{c}\text { Composite Shop } \\
\text { Level } 2 \text { to } \\
\text { Quality } \\
\text { Department }\end{array}$ & 76.2 & 78 \\
\hline $12 \rightarrow 13$ & $\begin{array}{c}\text { Quality } \\
\text { Department to } \\
\text { Composite Shop } \\
\text { Level } 2\end{array}$ & 76.2 & 78 \\
\hline $13 \rightarrow 14$ & $\begin{array}{l}\text { Composite Shop } \\
\text { Level } 2 \text { to } \\
\text { Painting Shop }\end{array}$ & 76.2 & 93 \\
\hline $\begin{array}{c}14 \rightarrow 15 \\
16,17,18, \\
19,20\end{array}$ & $\begin{array}{l}\text { Painting Shop to } \\
\text { Quality } \\
\text { Department }\end{array}$ & 129.54 & 140 \\
\hline & Total & 716.28 & 813 \\
\hline
\end{tabular}




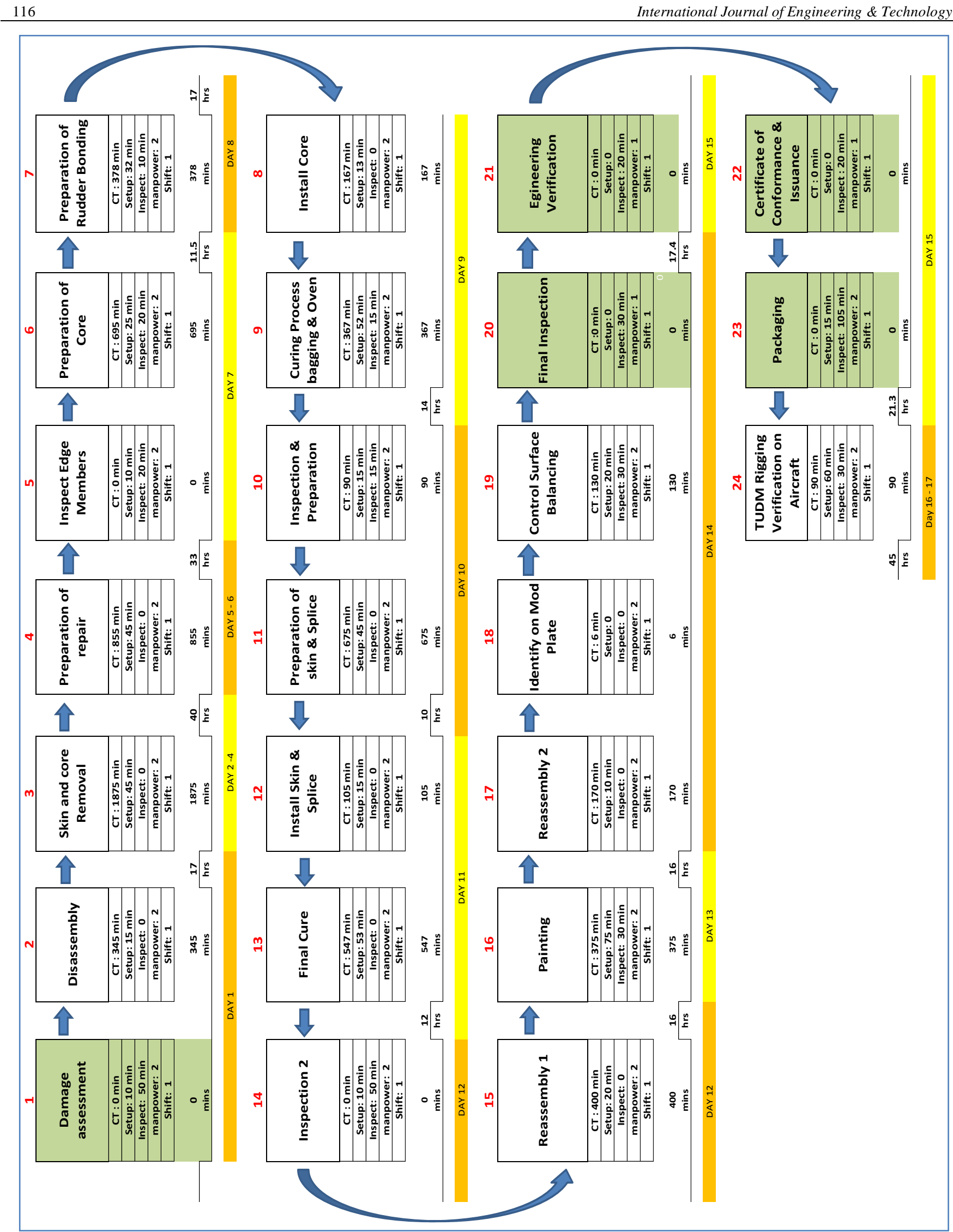

Fig. 2: Current state map 


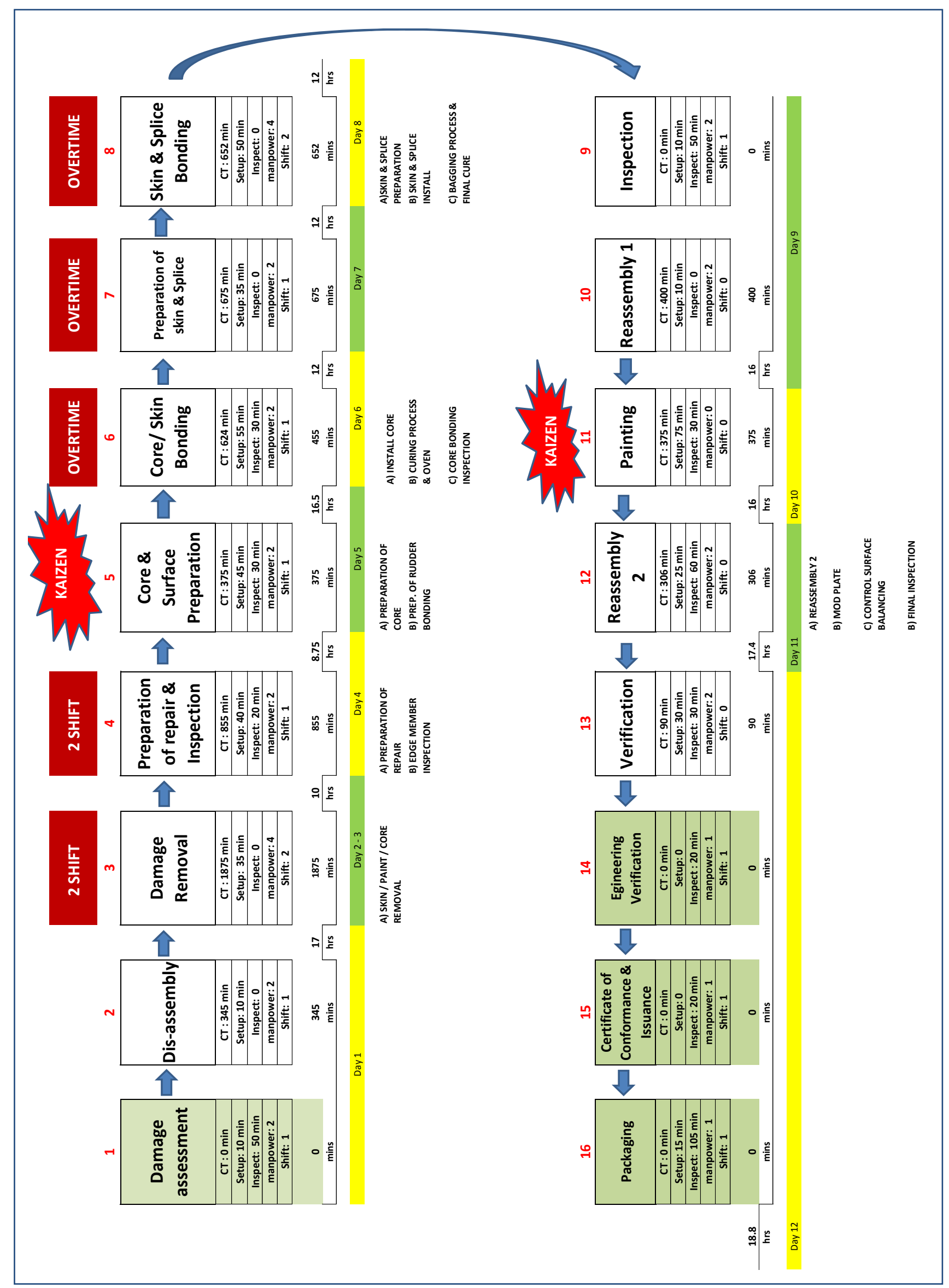

Fig. 3: Future state map 
Table 4: Improvement of time taken and distance of staff and part movement for rudder repair in future state map

\begin{tabular}{|c|c|c|c|}
\hline Process & Location & $\begin{array}{c}\text { Walking } \\
\text { Distances (m) }\end{array}$ & $\begin{array}{c}\text { Time Taken } \\
\text { (sec) }\end{array}$ \\
\hline $1 \rightarrow 2$ & $\begin{array}{l}\text { Warehouse to } \\
\text { Quality } \\
\text { Department }\end{array}$ & 38.1 & 47 \\
\hline $2 \rightarrow 3,4,5$ & $\begin{array}{c}\text { Quality } \\
\text { Department to } \\
\text { Composite Shop } \\
\text { Level } 2\end{array}$ & 76.2 & 78 \\
\hline $3,4,5 \rightarrow 6$ & $\begin{array}{l}\text { Composite Shop } \\
\text { Level } 2 \text { to Oven }\end{array}$ & 22.86 & 20 \\
\hline $6 \rightarrow 7$ & $\begin{array}{c}\text { Oven to } \\
\text { Composite Shop } \\
\text { Level } 2\end{array}$ & 22.86 & 20 \\
\hline $7 \rightarrow 7^{\prime}$ & $\begin{array}{l}\text { Composite Shop } \\
\text { Level } 2 \text { to Oven }\end{array}$ & 22.86 & 20 \\
\hline $7^{\prime} \rightarrow 8$ & $\begin{array}{c}\text { Oven to } \\
\text { Composite Shop } \\
\text { Level } 2\end{array}$ & 22.86 & 20 \\
\hline $8 \rightarrow 9$ & $\begin{array}{c}\text { Composite Shop } \\
\text { Level } 2 \text { to Paint } \\
\text { Shop }\end{array}$ & 76.2 & 93 \\
\hline $9 \rightarrow 10$ & $\begin{array}{c}\text { Paint Shop to } \\
\text { Composite Shop } \\
\text { Level } 2\end{array}$ & 76.2 & 90 \\
\hline $10 \rightarrow 11$ & $\begin{array}{c}\text { Composite Shop } \\
\text { Level } 2 \text { to } \\
\text { Quality Dept } \\
\end{array}$ & 76.2 & 78 \\
\hline $11 \rightarrow 12$ & $\begin{array}{l}\text { Quality Dept to } \\
\text { Warehouse }\end{array}$ & 38.1 & 44 \\
\hline \multicolumn{2}{|r|}{ Total } & 358.14 & 388 \\
\hline
\end{tabular}

From the data collected above, comparisons had been performed to identify the performance measures before and after the implementation of the lean approach. The indicators and their respective benefits were summarized in Table 5 .

Table 5: Performance indicators before and after lean implementation

\begin{tabular}{|c|c|c|c|}
\hline Indicators & $\begin{array}{l}\text { Current } \\
\text { State }\end{array}$ & $\begin{array}{l}\text { Future } \\
\text { State }\end{array}$ & Changes \\
\hline Number of rudder repair process & 24 & 16 & 8 \\
\hline $\begin{array}{l}\text { Total distances of movement for } \\
\text { rudder repair process (meter) }\end{array}$ & 716.28 & 358.14 & 358.14 \\
\hline $\begin{array}{l}\text { Total movement time of rudder } \\
\text { repair movement (second) }\end{array}$ & 813 & 388 & 425 \\
\hline $\begin{array}{l}\text { Total production cycle time of } \\
\text { rudder repair (second) }\end{array}$ & 7270 & 6403 & 867 \\
\hline $\begin{array}{l}\text { Changes percentage of } \\
\text { production cycle time }\end{array}$ & \multicolumn{3}{|c|}{$11.93 \%$} \\
\hline $\begin{array}{c}\text { Total waiting time of rudder } \\
\text { repair (hour) }\end{array}$ & 315.2 & 156.45 & 158.75 \\
\hline $\begin{array}{l}\text { Changes percentage of } \\
\text { waiting time }\end{array}$ & \multicolumn{3}{|c|}{$50.36 \%$} \\
\hline $\begin{array}{l}\text { Total production lead time of } \\
\text { rudder repair (day) }\end{array}$ & 17 & 12 & 5 \\
\hline $\begin{array}{c}\text { Changes percentage of production } \\
\text { lead time }\end{array}$ & \multicolumn{2}{|c|}{$29.41 \%$} & \\
\hline $\begin{array}{l}\text { Total setup time for rudder repair } \\
\text { process (second) }\end{array}$ & 585 & 445 & 140 \\
\hline
\end{tabular}

Due to the combined implementation of lean techniques, outcome of the process has improved in terms of faster response times and activities by the staffs in all of the repair processes. This can deliver significant financial benefit to the company. The value-added and non-value added activities are recognized through the Gemba walk. Few measurement indicators like the number of rudder repair processes, total movement time and total waiting time have shown significant advantage throughout the process implementation, which efficiently improves the previous lean wastes and repair processes. Table 6 shows the financial implication before and after the implementation of lean.
Table 6: Financial implication before and after lean implementation

\begin{tabular}{|c|c|c|c|}
\hline Items & $\begin{array}{c}\text { Current } \\
\text { State } \\
(\mathbf{R M})\end{array}$ & $\begin{array}{c}\text { Future } \\
\text { State } \\
(\mathbf{R M})\end{array}$ & $\begin{array}{c}\text { Cost } \\
\text { Saving } \\
(\mathbf{R M})\end{array}$ \\
\hline 2 x Manpower (Office hour) & 3201.78 & 3013.33 & $2.7 \%$ \\
\hline 2 x Manpower (Overtime) & 865.16 & 423.75 & $6.4 \%$ \\
\hline Transportation & 2700.00 & 900.00 & $26.2 \%$ \\
\hline General Overhead & 115.35 & 92.31 & $0.3 \%$ \\
\hline Total & $\mathbf{6 8 8 2 . 2 9}$ & $\mathbf{4 4 2 9 . 3 9}$ & $\mathbf{3 5 . 6 \%}$ \\
\hline
\end{tabular}

The numbers in Table 6 prove that lean implementation at Company X had favourably calculated cost savings of RM 2452.90 in the production process improvement. This agrees with the previous study that highlighted about the tangible benefit gained due to speedy response among the internal and external resources thus give significant impact to the financial benefits and cost [15]. The improvement in efficiencies such as reduction in wastes and defects will give advantage to the company and increase the profits of the project undertaken.

\section{Conclusion}

This research has eventually reached its objectives where the lean system can be sustained in competitive business environment, e.g. Company X's shortest lead-time in composite repair shop experiment was successful. The lean concept has now gained significance where it can improve the production performances, increase output quality, greater productivity and also cost reduction. Subsequently, an organization will gain the trust and customer satisfaction through effective customer service. The organization then becomes the preferred company for composite repair project that would eventually increase the market shares domestically and also internationally. It is highly recommended that this lean approach to be implemented in other aviation-related organizations such as approved training organizations [16] and airports [17] in order to not just increase productivity rate, but also minimizing costs at the same time to thrive in maintaining success.

\section{Acknowledgement}

Due to legality reasons, primary references and details which can potentially reveal identities of Company $\mathrm{X}$ and Company $\mathrm{Z}$ have been revised accordingly. Researchers would like to reiterate the acknowledgement for Company X and Company Z's full cooperation for this case study.

\section{References}

[1] Rahani A \& Al-Ashraf M (2012), Production flow analysis through value stream mapping: A lean manufacturing process case study. Procedia Engineering 41, 1727-1734

[2] Edtmayr T, Sunk A \& Sihn W (2016), An approach to integrate parameters and indicators of sustainability management into value stream mapping. Procedia CIRP 41, 289-294

[3] Locher D \& Keyte B (2016), The Complete Lean Enterprise Value Stream Mapping for Administrative and Office Processes. New York: Productivity Press.

[4] Tyagi S, Choudhary A, Cai X \& Yang K (2015), Value stream mapping to reduce the lead-time of a product development process. International Journal of Production Economics 160, 202-212

[5] Faulkner W \& Fazleena B (2014), Sustainable value stream mapping (Sus-VSM): Methodology to visualize and assess manufacturing sustainability performance. Journal of Cleaner Production 85, 8-18

[6] Rohac T \& Januska M (2015), Value stream mapping demonstration on real case study. Procedia Engineering 100, 520529

[7] Patel N, Chauhan N \& Trivedi P (2014), Benefits of value stream mapping as a lean tool implementation manufacturing industries: A review. International Journal for Innovative Research in Science \& Technology 1(8), 53-57

[8] Lacerda A, Xambre A \& Alvelos H (2015), Applying value stream mapping to eliminate waste: a case study of an original equipment 
manufacturer for the automotive industry. International Journal of Production Research 54(6), 1708-1720

[9] Brown A, Amundson J \& Badurdeen F (2014), Sustainable value stream mapping (Sus-VSM) in different manufacturing system configurations: Application case studies. Journal of Cleaner Production 85, 164-179

[10] US Environment Protection Agency (2016), https://www.epa.gov/ lean/types-waste-targeted-lean-methods

[11] Bakri A, Abdul Rahim AR, Mohd. Yusof N \& Ahmad R (2012), Boosting lean production via TPM. Procedia - Social and Behavioral Sciences 65, 485 - 491

[12] Evans JR \& Lindsay WM (2005), An Introduction to Six Sigma \& Process Improvement. South Western: Thomson

[13] Burch VR \& Smith B (2017), Using simulation to teach lean methodologies and the benefits for Millennials. Total Quality Management \& Business Excellence, 1-15

[14] Abdulmalek FA \& Rajgopal J (2007), Analyzing the benefits of lean manufacturing and value stream mapping via simulation: A process sector case study. International Journal of Production Economics 107(1), 223-236

[15] Liu C, Chiang M \& Chuang W (2012), Lean transformation for composite-material bonding processes. International Journal of Engineering and Technology Innovation 2(1), 48-62

[16] Khairuddin MH, Yahya MY \& Johari MK (2017), Critical needs for piston engine overhaul centre in Malaysia. IOP Conference Series: Materials Science and Engineering 270, 012013

[17] Bardai A, Er A, Johari M \& Mohd Noor A (2017), A review of Kuala Lumpur International Airport (KLIA) as a competitive South-East Asia hub. IOP Conference Series: Materials Science and Engineering 270, 012039 